\title{
Etiologia e Prevalência da Mastite de Origem Bacteriana em Animais Livres e Portadores de Artrite-Encefalite Caprina ${ }^{1}$
}

Lauana Borges Santiago², Roberta Lomonte Lemos de Brito ${ }^{2}$, Vanderlan Warlington Souza dos Santos ${ }^{3}$, Apoliana de Sousa Rodrigues ${ }^{4}$, Alice Andrioli ${ }^{5}$, Francisco Selmo Fernandes Alves 5 ,

Raymundo Rizaldo Pinheiro ${ }^{6}$

Resumo: A manifestação clínica na glândula mamária da Artrite-Encefalite Caprina (CAE) é freqüente e tem grande significado econômico na caprinocultura ao comprometer a produção leiteira e predispor a glândula mamária a infecções secundárias. Objetivou-se com este estudo determinar a prevalência e isolar e identificar os microrganismos causadores de mastite em animais livres e portadores de CAE. Foram utilizadas 44 cabras mestiças Saanen x Anglo-Nubiana, sendo 19 positivas para a CAE e 25 livres da enfermidade. As amostras de leite para o microbiológico foram coletadas de cada teto, durante sete meses, plaqueadas em Ágar Sangue e mantidas sob incubação a $37^{\circ} \mathrm{C}$ por $48 \mathrm{~h}$, totalizando 588 amostras. As colônias foram caracterizadas macro e microscopicamente. Posteriormente foram submetidas às provas bioquímicas de acordo com a suspeita microbiológica. Em relação ao grupo de animais infectados pela CAE, $28,17 \%$ das amostras analisadas foram microbiologicamente positivas, e no rebanho negativo, $18,15 \%$ obtiveram resultado positivo. Foi constatada diferença estatística significativa $(p<0,01)$ entre os grupos, demonstrando maior incidência de mastite bacteriana no grupo infectado com CAE. Em relação à identificação dos microrganismos isolados, não houve diferença estatística significativa entre os grupos. Staphylococcus sp. coagulase negativa foi identificado em 95,77\% das amostras positivas ao exame microbiológico, no grupo de animais infectados pela CAE, e em 93,44\% no rebanho livre da doença.

Palavras-chave: caprinos, exame microbiológico, glândula mamária, microrganismos, retrovírus

\section{Aetiology and Prevalence of Bacterial Mastitis in Groups of Goats Free and Infected by Caprine Arthritis Encephalitis}

\begin{abstract}
The clinical manifestation of Caprine Arthritis Encephalitis (CAE) is usual and means economic losses for dairy goats, decreasing milk production and increasing susceptible of mammary gland to bacterial infections. The aim of the study was to determinate the etiology and prevalence of mastitis in groups of free and infected goats by CAE. It were utilized 44 crossbreed does Saanen x Anglo- Nubiana. One group was composed for 19 females positive for CAE and another group, for 25 negative ones. Milk microbiological exam was accomplished for seven months, of each teat, once at a month, totalizing 588 samples. It were plated in Blood Agar Base and kept at $37^{\circ} \mathrm{C}$ for $48 \mathrm{~h}$. Colonies were characterized macro and microscopically and, then, all biochemical tests were realized. For the CAE infected group, 28,17\% of all samples were positives
\end{abstract}

${ }^{1}$ Estudo financiado pela EMBRAPA Caprinos, Banco do Nordeste do Brasil - BNB e Fundação Cearense de Apoio ao Desenvolvimento Científico e Tecnológico - FUNCAP

${ }^{2}$ Mestranda em Zootecnia - Universidade Estadual Vale do Acaraú (UVA)/Embrapa Caprinos. Bolsista FUNCAP

${ }^{3}$ Graduando em Zootecnia - UVA. Bolsista FUNCAP

${ }^{4}$ Graduanda em Biologia - UVA, Bolsista FUNCAP

${ }^{5}$ Médica (o) Veterinária (o) - Pesquisador da Embrapa Caprinos

${ }^{6}$ Orientador - Pesquisador da Embrapa Caprinos e Professor do Curso de Graduação em Zootecnia da UVA. Estrada Sobral - Groaíras, Zona Rural, Km 4, CEP: 62011-970, caixa postal 145, Sobral, CE . E-mail: rizaldo@cnpc.embrapa.br (autor para correspondência) 
Rev. Cient. Prod. Anim., v.12, n.2, p.223-226, 2010

by microbiological exam and, for the negative group, only $18,15 \%$. Statistical difference significant $(\mathrm{p}<0,01)$ was observed, showing highest bacterial mastitis incidence on the infected group. Considering the aetiology, it wasn't noted significant statistical difference between both groups. Coagulase negative Staphylococcus sp. was identified in $95,77 \%$ of positive samples for microbiological exam, on the CAE infected group, and in $93,44 \%$ on the negative group.

Key words: caprine, microbiological exam, microorganisms, mammary gland, retrovirus

\section{Introdução}

A Artrite Encefalite Caprina (CAE) é uma enfermidade persistente e incurável de caprinos, causada por um retrovírus não-oncogênico (CAEV) e caracterizada por um longo período de incubação. A infecção causa uma doença multi-sistêmica, de evolução geralmente crônica, com agravamento progressivo das lesões e debilidade até a morte (Pinheiro et al., 2000). As perdas econômicas causadas se caracterizam pela morte de animais jovens, queda na produção e qualidade do leite e perda de peso de animais adultos, devido a dificuldades de locomoção. Perdas indiretas importantes são decorrentes da desvalorização dos rebanhos, reposição precoce de animais, despesas com medidas de controle e barreiras comerciais para produtos como matrizes, reprodutores e sêmen (Pinheiro, 2001). A manifestação clínica da $\mathrm{CAE}$ na glândula mamária é freqüente e tem também, grande significado econômico na caprinocultura ao comprometer a produção leiteira e predispor a glândula mamária a infecções secundárias (Lerondelle, 1988). O objetivo deste estudo foi isolar e identificar os microrganismos causadores de mastite bacteriana em animais livres e portadores de CAE e determinar a prevalência da infecção, através da realização mensal de exame microbiológico de amostras de leite, ao longo de um período de sete meses.

\section{Material e Métodos}

O presente estudo foi realizado na Fazenda Santa Rita, unidade experimental da EMBRAPA Caprinos, localizada no município de Sobral - CE, numa região semi-árida do sertão cearense, a $3^{\circ} 42^{\prime}$ de latitude Sul e $40^{\circ} 21^{\prime}$ de longitude Oeste, numa altitude de $83 \mathrm{~m}$. Foram utilizadas 44 matrizes caprinas mestiças Anglonubiana x Saanen, sendo 19 positivas para a ArtriteEncefalite Caprina (CAE) e 25 livres da enfermidade, mantidas em pastagem irrigada de capim Tanzânia, com acesso ad libitum à água e suplementação mineral. As cabras eram recém paridas, com faixa etária entre 14 e 38 meses, escore corporal entre 1,75 e 2,5 e peso entre 33 e $39 \mathrm{Kg}$. As coletas de leite foram iniciadas 15 dias após o parto no período de janeiro a julho de 2008, totalizando 588 amostras. O exame microbiológico das amostras foi realizado, ao final de cada mês, individualmente por teto, no Laboratório de Bacteriologia da Embrapa Caprinos, de acordo com metodologia descrita por Carter et al. (1986). A coleta de leite foi realizada, de forma asséptica, em tubos de ensaio de $10 \mathrm{~mL}$ estéreis, após higienização do teto com álcool a 70\% e secagem com toalha de papel. O leite coletado foi armazenado em recipiente térmico com gelo reciclável e transportado ao laboratório, onde foi imediatamente submetido às análises. As amostras foram plaqueadas em Ágar Base contendo $5 \%$ de sangue ovino e as placas mantidas sob incubação a $37^{\circ} \mathrm{C}$ por $48 \mathrm{~h}$. As colônias foram caracterizadas macroscopicamente, quanto ao aspecto, coloração, tamanho e tipo de hemólise, e microscopicamente pelo método de Gram. Posteriormente foram submetidas às provas de catalase, coagulase, urease e/ou fermentação de carboidratos, de acordo com as características microbiológicas da colônia estudada. 
A partir dos resultados obtidos e da associação dos dados coletados, foi realizada a identificação do agente causador da mastite. A análise estatística dos dados foi realizada através do programa estatístico EPI-INFO 6.0.

\section{Resultados e Discussão}

De um total de 252 amostras de leite provenientes do grupo de animais infectados pela CAE, submetidas ao exame microbiológico, $71(28,17 \%)$ obtiveram resultado positivo. Quanto ao rebanho negativo para CAE, das 336 amostras analisadas, 61 (18,15\%) foram microbiologicamente positivas (Figura 1). A análise estatística de tais valores constatou diferença estatística significativa $(\mathrm{p}<0,01)$ entre os grupos experimentais, demonstrando maior incidência de mastite bacteriana nos grupos de animais acometidos pela CAE em comparação ao grupo de animais livres desta enfermidade. Estes resultados parecem estar relacionados à maior susceptibilidade dos animais infectados pelo $\mathrm{CAEV}$, às infecções bacterianas secundárias, como afirma Lerondelle (1988). Entretanto, a queda na resistência imunológica geral dos animais acometidos pela CAE ainda é um aspecto bastante discutido na literatura, já que os linfócitos são caracterizados como a população leucocitária mais importante na resposta imune e estas, não são as células de predileção do vírus; e sim, as células do sistema monocítico-fagocitário (Pinheiro,
2001). Por outro lado, é importante ressaltar que o comprometimento da glândula mamária decorrente da virose, associado ao agravamento progressivo das lesões da CAE, certamente atua como fator estressante e pode ser responsável pela baixa na imunidade e, conseqüentemente maior incidência de mastite no rebanho infectado. As porcentagens de amostras microbiologicamente positivas em relação ao número total de amostras, por coleta em cada grupo, ao longo dos sete meses, estão representadas na Figura 2. Em relação à identificação dos microrganismos isolados, não foi observada diferença estatística significativa entre os grupos analisados. Staphylococcus sp. coagulase negativa foi identificado em 68 (95,77\%) das 71 amostras positivas ao exame microbiológico do grupo de animais infectados pela CAE e Staphylococcus aureus, Streptococcus sp. e Pasteurella sp. em somente uma amostra (1,41\%), cada um. No grupo de animais livres da doença, foi isolado Staphylococcus sp. coagulase negativa em $57(93,44 \%)$ das 61 amostras microbiologicamente positivas. Staphylococcus aureus e Streptococcus sp. foram identificados, cada um, em duas $(3,28 \%)$ de todas as amostras positivas do grupo. Tais resultados estão de acordo com estudo de Bergonier et al. (2003), onde o Staphylococcus é citado como o principal agente causador da infecção da glândula mamária em pequenos ruminantes, sendo o $S$. aureus mais comum na mastite clínica e o Staphylococcus sp. coagulase negativa predominante na mastite subclínica.

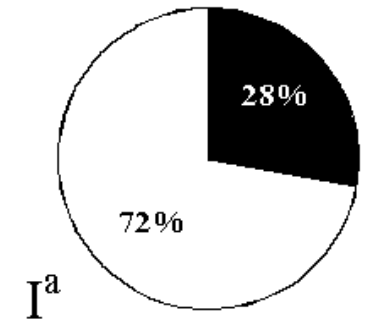

Figura 1 - Porcentagem de amostras de leite positivas e negativas no exame microbiológico em relação ao número de amostras total do grupo, no rebanho de animais infectados (I) e livres (II) do vírus da Artrite Encefalite Caprina (CAEV); letras minúsculas diferentes representam diferença estatística significativa $(\mathrm{p}<0,01)$ 


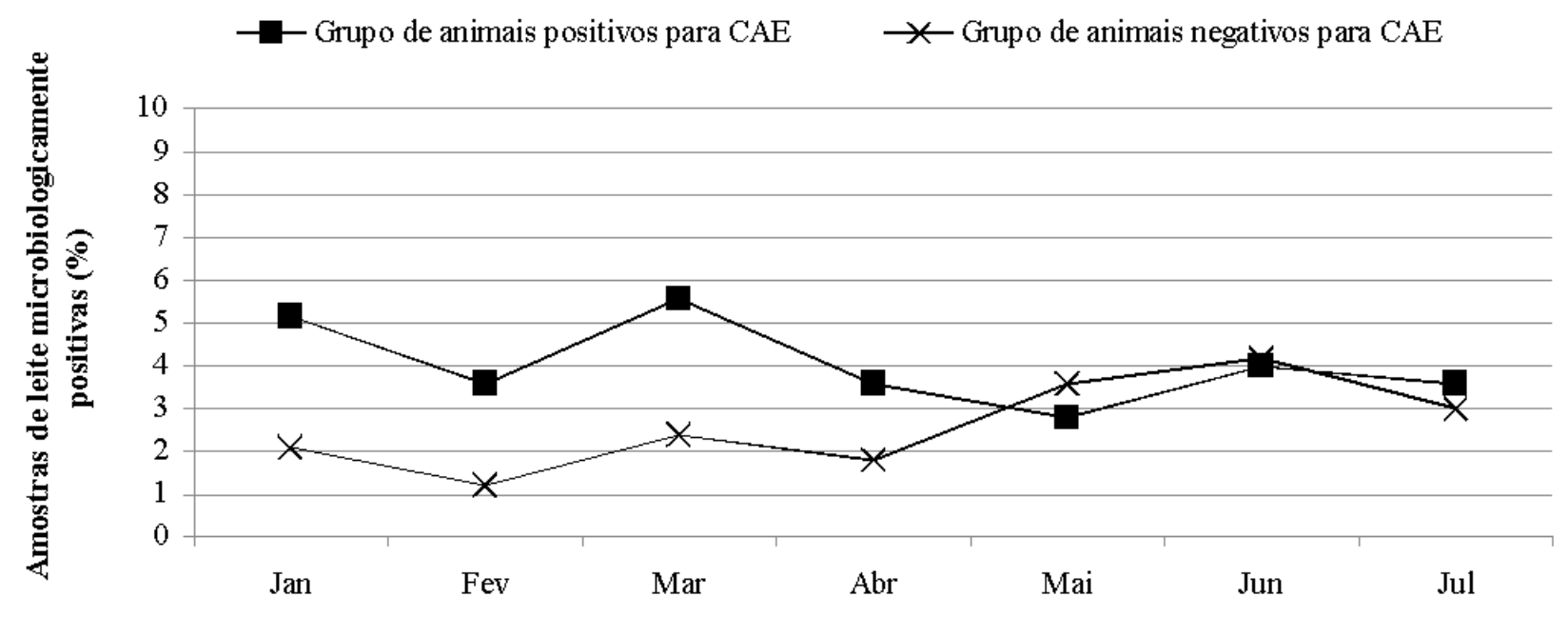

Tempo (meses)

Figura 2 - Porcentagem de amostras de leite microbiologicamente positivas em relação ao número total de amostras por coleta e por grupo, nos rebanhos de animais infectados e livres do vírus da Artrite Encefalite Caprina, ao longo dos sete meses de coleta

\section{Conclusões}

Foi constatada maior incidência de mastite de origem bacteriana no grupo de animais infectados pela Artrite Encefalite Caprina em relação ao grupo de animais livres da enfermidade, durante sete meses de lactação. Torna-se necessária a realização de outros estudos para identificação das reais causas deste achado. Staphylococcus sp. coagulase negativa atuou como o principal agente causador da mastite bacteriana em ambos os grupos.

\section{Literatura Citada}

BERGONIER, D.; CRÉMOUX, R.; RUPP, R.; LAGRIFFOUL, G.; BERTHELOT, X. Mastitis of dairy small ruminants. Veterinary Research, v. 34, p. 689-716, 2003.

\section{CARTER, G. R.; CLAUS, W.; RIKIHISA, Y.} Essencials of veterinary bacteriology and mycology. 3.ed. Philadelphia: Lea \& Febiger, 1986. 261 p.
LERONDELLE, C. Mammary infection caused by caprine arthritis encephalitis virus (CAEV). Sciences Veterinaires Medecine Comparee, v. 90, n. 3, p. 139143, 1988.

PEREIRA, M. F. Artrite Encefalite Caprina a Vírus (CAE) - estudo anátomo-patológico e imunohistoquímico em cabras naturalmente infectadas. Belo Horizonte: Escola de Veterinária da UFMG, 1995. 64p. Dissertação (Mestrado em Medicina Veterinária).

PINHEIRO, R. R. Vírus da Artrite Encefalite Caprina: desenvolvimento e padronização de ensaios imuno-enzimáticos (ELISA e Dot-Blot) e estudo epidemiológico no Estado do Ceará. Belo Horizonte: Escola de Veterinária da UFMG, 2001. 115p. Tese (Doutorado em Ciência Animal).

PINHEIRO, R. R.; ALVES, F. S. F. Parâmetros clínicos, exame do líquido sinovial e hemograma na Artrite Encefalite Caprina Viral. Revista Brasileira de Medicina Veterinária, v. 20, p. 263-264, 2000. 